\title{
Geomechanical evaluation of macro-block caving options using 3D numerical modelling at Chuquicamata underground project in Chile
}

\author{
E. Hormazabal SRK Consulting, Chile \\ F. Villegas VCP-Codelco Chile, Chile \\ F. Rovira SRK Consulting, Chile \\ C. Carranza-Torres University of Minnesota, United States of America
}

\begin{abstract}
The Chuquicamata underground project in the Atacama Desert in northern Chile is one of the largest planned mining projects in the world to use the block caving method with macro-blocks options, to mine copper ore. VCP-Codelco (Vice-President Office of the National Copper Corporation of Chile) is currently completing a prefeasibility engineering study of this project, which considers the construction and operation of at least two macro-block mining units to be managed independently from each other. A geomechanical study has been carried out to analyse various options regarding to pillar sizes and mining sequences for the macro-blocks caving configurations considered for the project. As part of this study, complex $3 D$ continuum models have been developed to assess the effects of the above options on the mechanical response of the underground openings, with emphasis in stress concentration in certain critical areas of the excavations such as macro-blocks pillars and rib-pillars. Relevant geological features such as major faults and lithological units were also considered in the models. This paper describes the main aspects of the Chuquicamata underground project by focusing on the $3 D$ numerical models that were performed to evaluate the macro-block extraction options for this block cave.
\end{abstract}

\section{Introduction}

The Chuquicamata underground project in the Atacama Desert in northern Chile (see Figure 1) is one of the largest planned block caving operations in the world. The mining project contemplates the implementation of a block cave method with macro-blocks options to extract copper ore (Codelco, 2007; VCP-Codelco, 2009; SRK Consulting Ltda., 2008, 2009). VCP-Codelco is already finishing a prefeasibility engineering study for this project, which considers the construction and operation of at least two macro-block mining units to be operated independently from each other. A critical design aspect for this project corresponds to controlling potential stress concentrations in certain critical areas of the excavations, such as pillars abutments and rib-pillars. This paper describes the main aspects of the Chuquicamata underground project by focusing on the $3 \mathrm{D}$ numerical models that were performed to evaluate the macro-block extraction options for this block cave.

\section{Geological and geotechnical units for Chuquicamata underground project}

The Chuquicamata porphyry copper deposit is a prismatic body that dips towards the west. Figure 2 shows a plan view of the deposit at the extraction level (located $1,841 \mathrm{~m}$ above sea level). Mineralisation was controlled by the West Fault which forms the hangingwall of the deposit. The West Fault is a major regional fault with almost north-south trend, 4-6 m in thickness and an associated 150-200 m wide shear or breccia zone (see Figure 2). The predominant rock types in the underground mine will correspond to granodiorites and porphyries in contact with the West Fault. This last area represents a shear zone with poor to very poor geotechnical quality. On the eastern side of the West Fault a massive quartz-sericitic rock unit occurs; beyond this, porphyries with different types of alteration are present. The main rock mass types at Chuquicamata underground project are summarised in Figure 2. A simplified set of geotechnical units considered in this study is shown in Figure 3. 
The geotechnical characterisation of the Chuquicamata underground site has been carried out based on geological-geotechnical borehole logging and surface mapping information (Karzulovic, 2007). The quality of the rock mass has been rated using the rock mass rating (RMR) system by Laubscher (1990) and GSI by Hoek et al. (2002). The rock mass properties for the geotechnical units have been determined by the HoekBrown failure criterion (Hoek, 1994) using the software ROCLAB (available from wwww.rocscience.com). Laboratory testing results, unconfined and triaxial compression tests of intact core-logging samples, were used as input data for the Roclab analysis. Estimation of rock mass properties calibrations have been also conducted in exploration drifts (Karzulovic, 2007). Table 1 summarises mean geotechnical properties parameters for the various rock mass units considered in the 3D models.

The pre-mining in situ stress field was provided by VCP-Codelco (2009) and is given by the following principal stress components:

$$
\begin{gathered}
\sigma_{\mathrm{v}}=0.026 \times h[\mathrm{MPa}] \\
\sigma_{E W}=0.033 \times \sigma v+9.7[\mathrm{MPa}] \\
\sigma_{N S}=0.033 \times \sigma v+10.0[\mathrm{MPa}]
\end{gathered}
$$

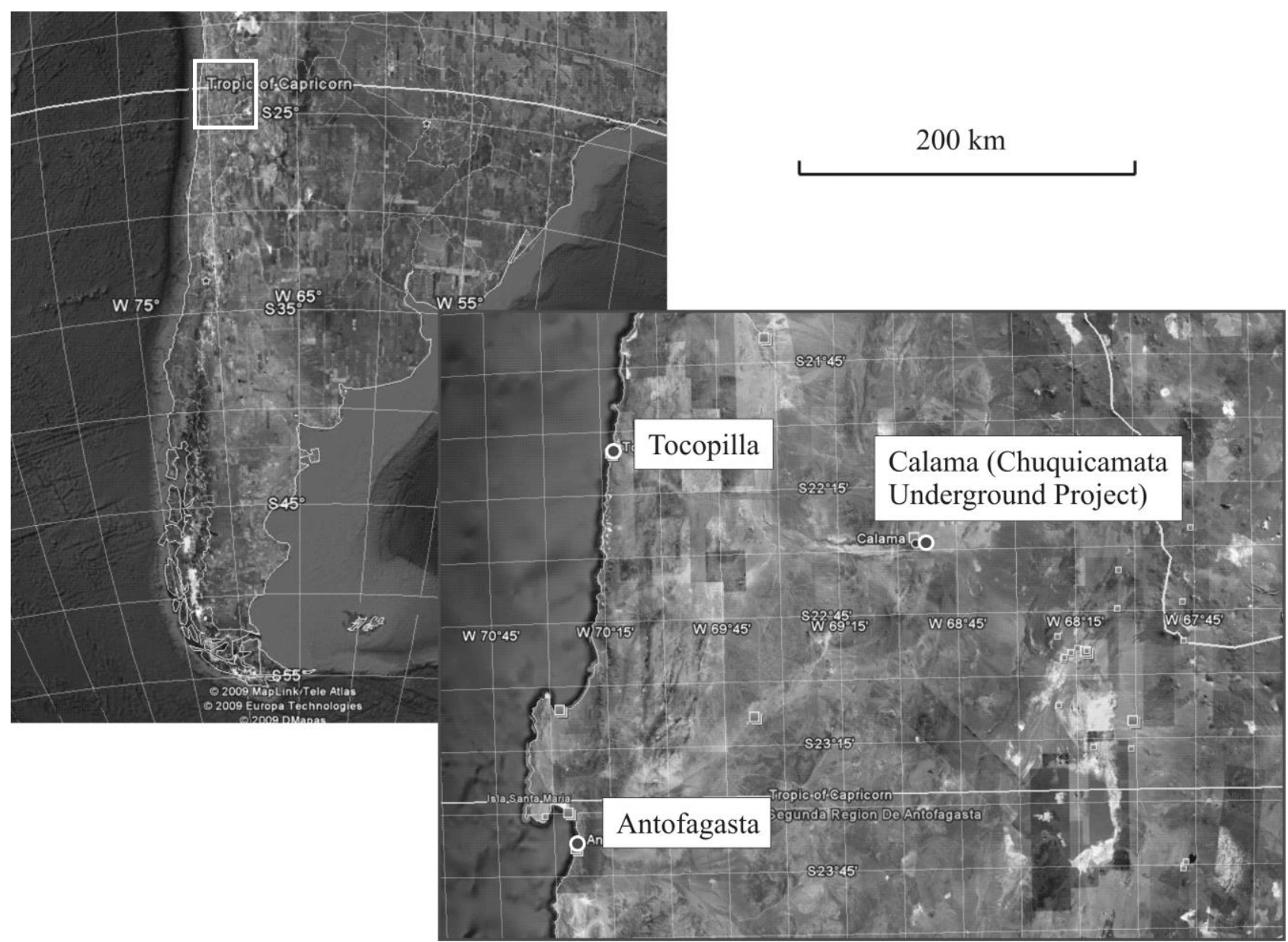

Figure 1 Chuquicamata mine location, in relation to Antofagasta and Calama cities in northern Chile 


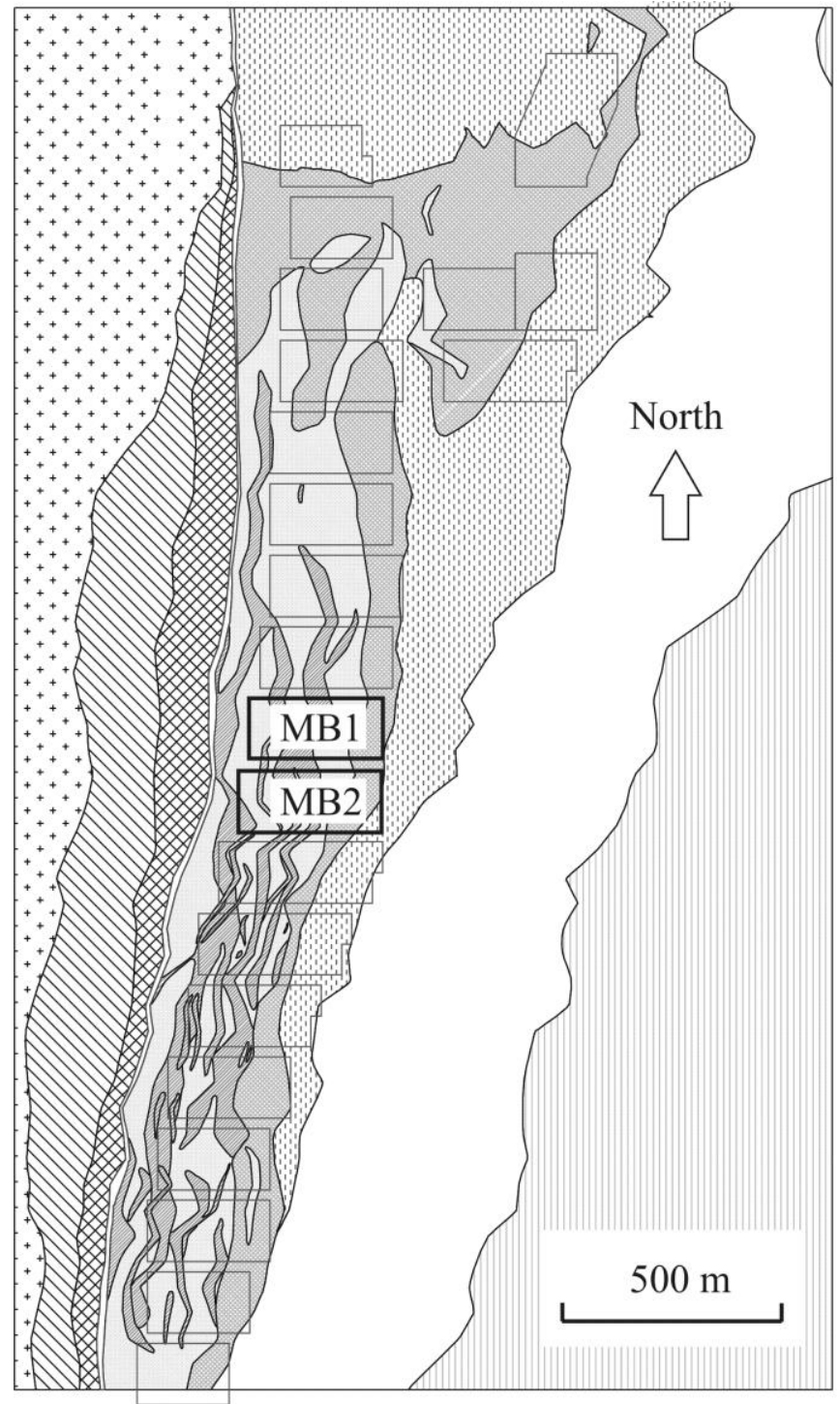

\begin{tabular}{|c|c|}
\hline \multicolumn{3}{|c|}{ GEOTECHNICAL UNITS } \\
\hline RQS (Q=S) & Quartz Sericitic Rock (Quartz = Sericite) \\
RQS (Q>S) & Quartz Sericitic Rock (Quartz > Sericite) \\
RQS (Q<S) & Quartz Sericitic Rock (Quartz < Sericite) \\
PEC & East Porfhyry with Chloritic Alteration \\
PEK & East Porfhyry with Potassic Alteration \\
PES & East Porfhyry with Sericitic Alteration \\
GES & South Elena Granodiorite \\
ZCM & Moderately Shear Zone \\
\hline ZCI & Intense Shear Zone \\
\hline GDF & Fortuna Granodionite \\
\hline FW & West Fault \\
\hline
\end{tabular}

Figure 2 Plan view of the geotechnical units considered for the Chuquicamata underground site (the plan view corresponds to the extraction level, located $1,841 \mathrm{~m}$ above sea level). The rectangles in thin outline depict the various macro-blocks units considered in the project. The rectangles in thick outline represent the two macro-blocks units (MB1 and MB2) analysed as part of this study 


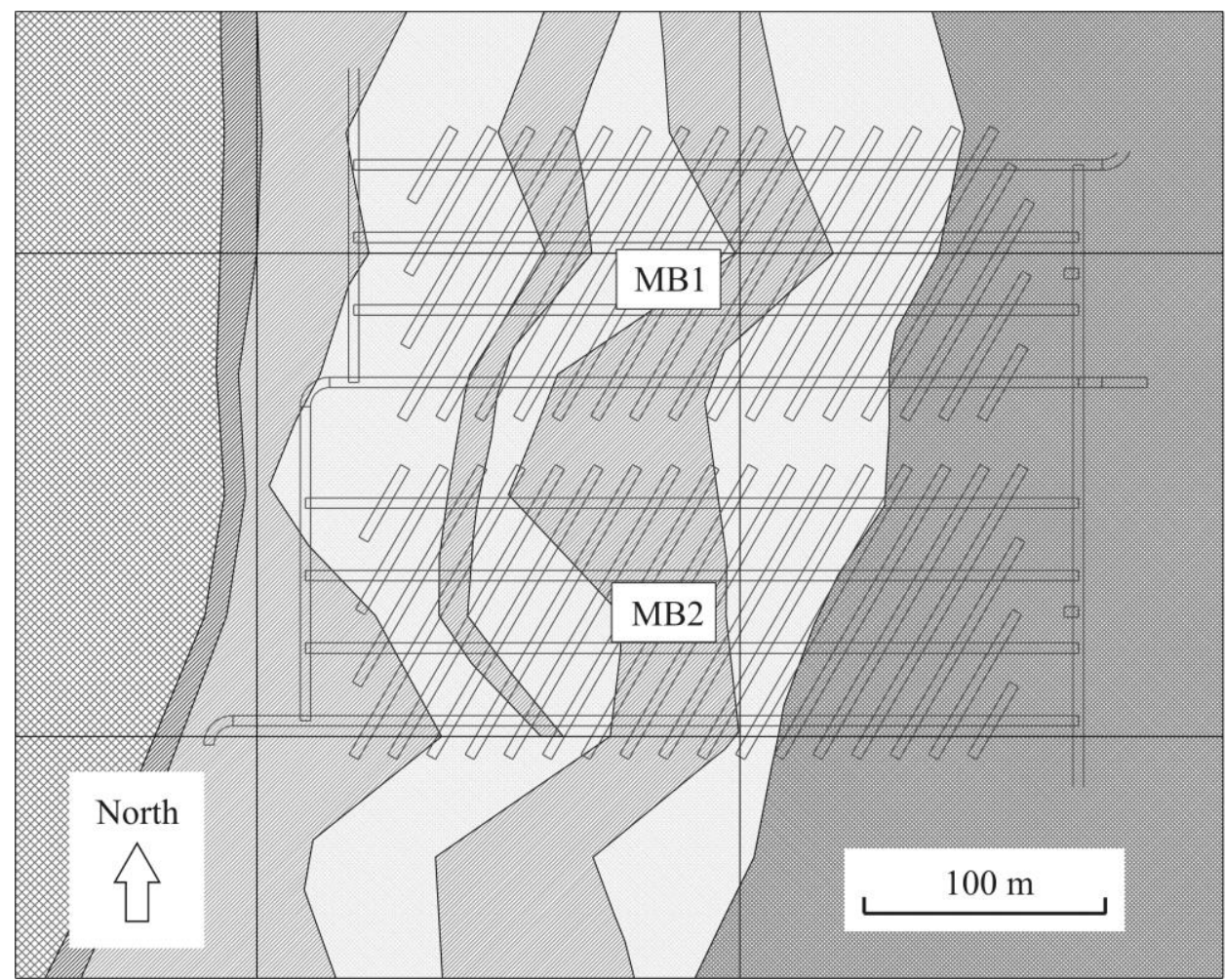

- PES

Production Level Layout (1841)

Figure 3 Plan of geotechnical units and underground infrastructure layout for the two macro-blocks units considered in this study (extraction level representation)

Table 1 Summary of geotechnical properties for the various geotechnical units considered in the 3D elasto-plastic models - mean values of properties are indicated

\begin{tabular}{lccccccccc}
\hline Geotechnical Unit & $\begin{array}{c}\gamma \\
\left(\mathbf{K N} / \mathbf{m}^{\mathbf{3}}\right)\end{array}$ & $\begin{array}{c}\boldsymbol{\sigma}_{\boldsymbol{c} i} \\
(\mathbf{M P a})\end{array}$ & $\begin{array}{c}\boldsymbol{m}_{\boldsymbol{i}} \\
(-)\end{array}$ & $\begin{array}{c}\text { GSI } \\
(-)\end{array}$ & $\begin{array}{c}\boldsymbol{\sigma}_{t} \\
(\mathbf{M P a})\end{array}$ & $\begin{array}{c}\boldsymbol{E} \\
(\mathbf{G P a})\end{array}$ & $\begin{array}{c}\boldsymbol{v} \\
(-)\end{array}$ & $\begin{array}{c}\boldsymbol{c} \\
(\mathbf{k P a})\end{array}$ & $\begin{array}{c}\boldsymbol{\phi} \\
(\mathbf{d e g})\end{array}$ \\
\hline RQS $(\mathrm{Q}<\mathrm{S})$ & 25.9 & 15 & 25 & 41 & 0.06 & 9.38 & 0.20 & 2,665 & 35 \\
$\mathrm{RQS}(\mathrm{Q}>\mathrm{S})$ & 26.7 & 89 & 10.5 & 60 & 0.88 & 22.57 & 0.20 & 4,700 & 41 \\
RQS $(\mathrm{Q}=\mathrm{S})$ & 26.6 & 52 & 11.9 & 52 & 0.46 & 13.48 & 0.20 & 3,670 & 38 \\
BEF (West fault zone) & 25.1 & 37 & 17.0 & 33 & 0.02 & 1.06 & 0.28 & 1,910 & 29 \\
ZCI (Intense shear zone) & 23.0 & 20 & 17.0 & 32 & 0.01 & 0.82 & 0.28 & 1,435 & 25 \\
Broken material & 20.0 & - & - & - & - & 1.03 & 0.29 & 200 & 38 \\
\hline
\end{tabular}

Note: $\gamma$ is the bulk unit weight of the rock mass; $\boldsymbol{\sigma}_{\boldsymbol{c}}$ is the unconfined compression strength of intact rock; $\boldsymbol{m}_{i}$ is the Hoek-Brown parameter; GSI is the Geological Strength Index; $\boldsymbol{\sigma}_{\boldsymbol{t}}=$ is the uniaxial tensile strength of the rock mass; $\boldsymbol{E}$ the rock mass Young's Modulus; $\boldsymbol{v}$ is Poisson's ratio; $\boldsymbol{c}$ is the equivalent rock mass cohesion; $\boldsymbol{\phi}$ is the equivalent rock mass internal friction angle parameters; $\boldsymbol{E}, \boldsymbol{v}, \boldsymbol{c}$ and $\boldsymbol{\phi}$ computed with software ROCLAB, using a confined stress of $\sigma_{c i}<10 \mathrm{MPa}$.

\section{$3 \quad$ Numerical modelling overview}

\subsection{Objective}

The main objective of the numerical modelling corresponds to quantifying stress concentrations in certain critical areas of the planned infrastructure: access, drifts, pillars, rib-pillars, etc. The most relevant assumptions are summarised below. 


\subsection{Assumptions and considerations}

Drifts and galleries for the extraction and undercut levels have been considered by a $4 \mathrm{~m}$ square cross section; $14 \mathrm{~m}$ undercutting height and $25 \mathrm{~m}$ of undercut advance were considered; a $16 \mathrm{~m}$ (from floor to floor) crown pillar was analysed; caving scheme corresponds to 'El Teniente' layout for the extraction level excavations with an associated $15 \times 16 \mathrm{~m}$ grid; conventional block caving method with macro-block variant was considered; a $10 \mathrm{~m}$ uniform thickness West Fault zone was incorporated into the analysis.

Six different caving options have been considered in the study. These options, referred to as caving options \#1 through caving options \#6, do have the following characteristics:

- Caving option \#1: a pillar of width $20 \mathrm{~m}$ is left at the undercutting level between macro-blocks MB1 and MB2.

- Caving option \#2: a pillar of width $30 \mathrm{~m}$ is left at the undercutting level between macro-blocks MB1 and MB2.

- Caving option \#3: this caving option is similar to the caving option 1, except that the pillar at the undercutting level next to macro-block MB1 is removed before preparation of macro-block MB2 takes place.

- Caving option \#4: the option is similar to the caving option 2, except that the pillar at the undercutting level next to macro-block MB1 is removed before preparation of macro-block MB2 takes place.

- Caving option \#5: the option is similar to the caving option 1, except that the pillar at the undercutting level next to macro-block MB2 is removed during extraction of the macro-block MB1.

- Caving option \#6: the option is similar to the caving option 2, except that the pillar at the undercutting level next to macro-block MB2 is removed during extraction of the macro-block MB1.

Figures 4 and 5 show the different caving options considered in the study. The figures also indicate the mining sequence (i.e. caving progress in time) provided by VCP-Codelco (Hoek, 1994). The numerical models for this project have been generated using the FLAC3D code (www.itasca.com). Detailed geometrical features of the caving infrastructure, as well as the lithological units encountered at the underground project, were incorporated into the models, as shown in Figures 6 to 8. Numerical algorithms, that takes into account the current modelling practices, were developed with the purpose of incorporating the geomechanical parameters into the numerical model - see for example (HCItasca-SRK, 2006).

Although the constituting materials that were included into the model do not describe a rheological behaviour, the models account for a 'time' component associated with excavations sequencing. For example, each of the caving options previously described (see Figures 4 and 5) comprises 21 excavation phases. Each excavation phase comprises an 11 years period. 

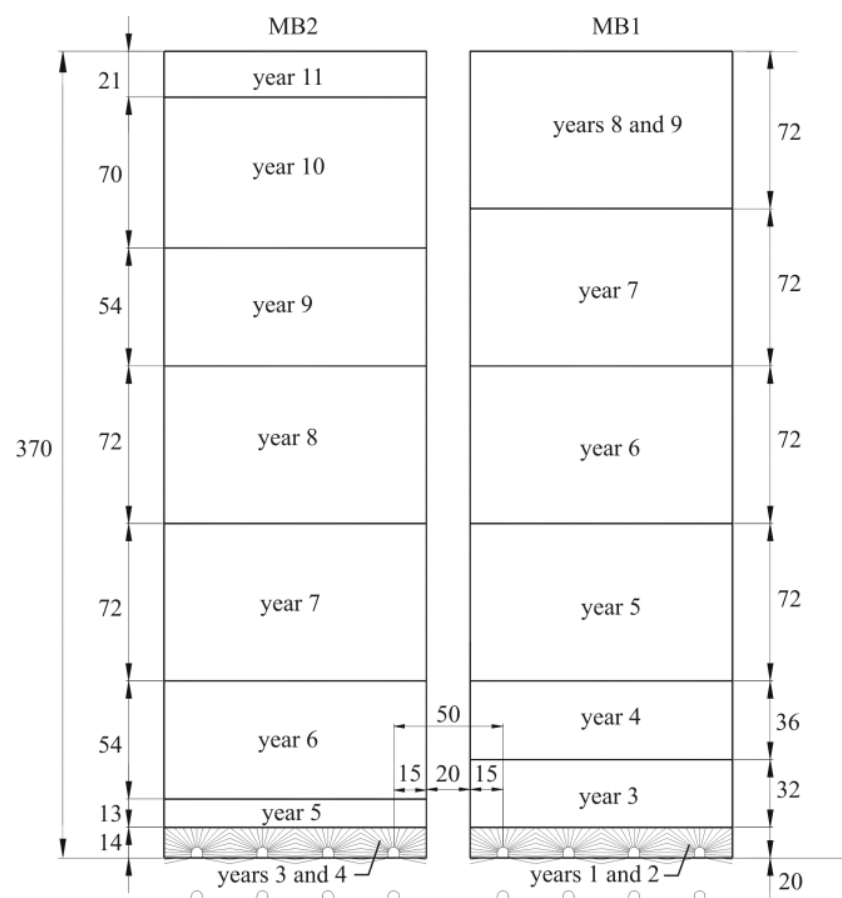

Caving Option \#1

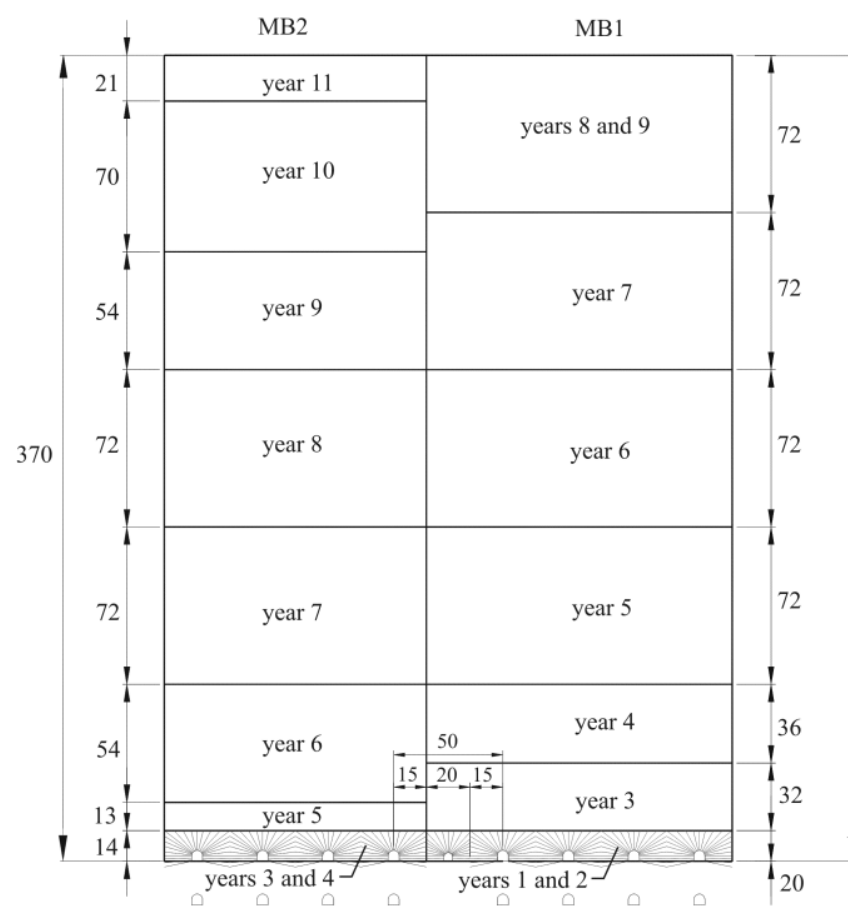

Caving Option \#3

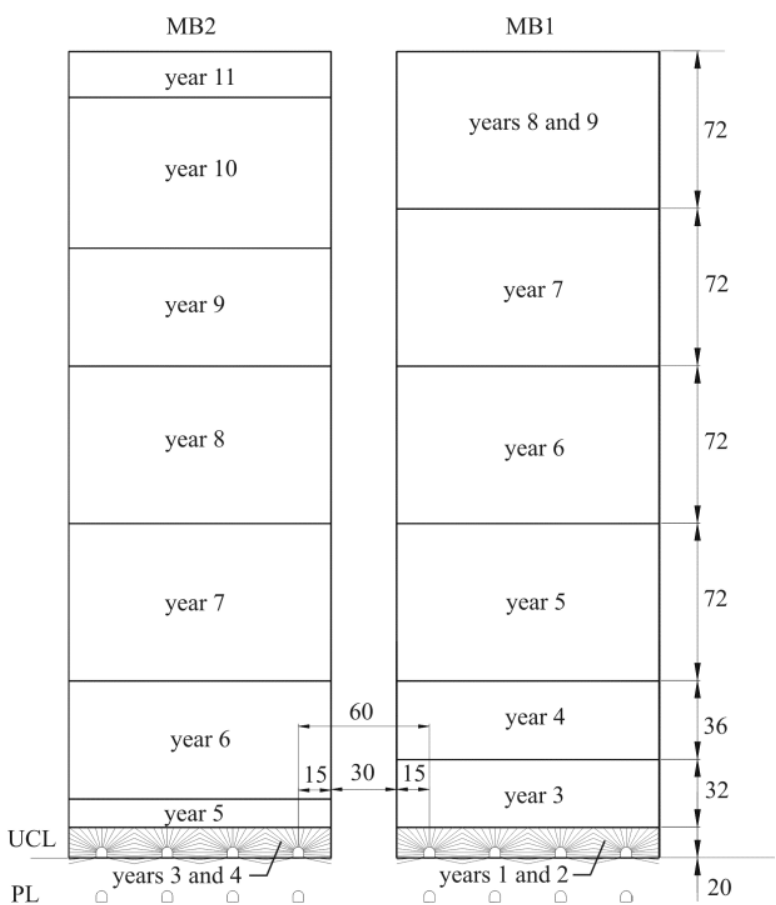

Caving Option \#2

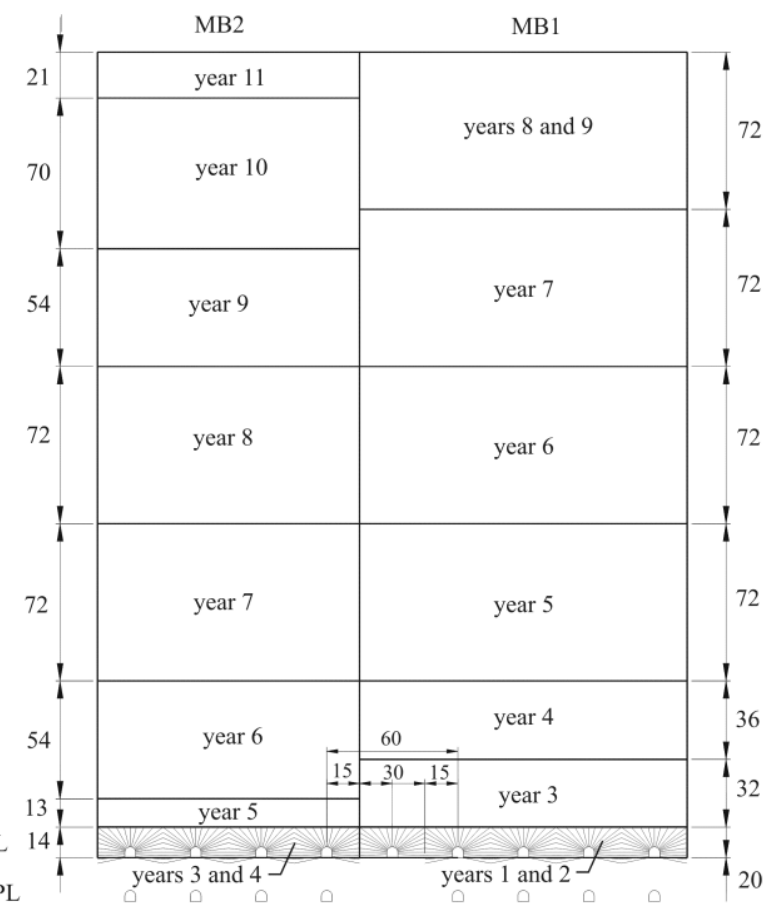

Caving Option \#4

Figure 4 Caving options \#1 to \#4 analysed by 3D elasto-plastic models 


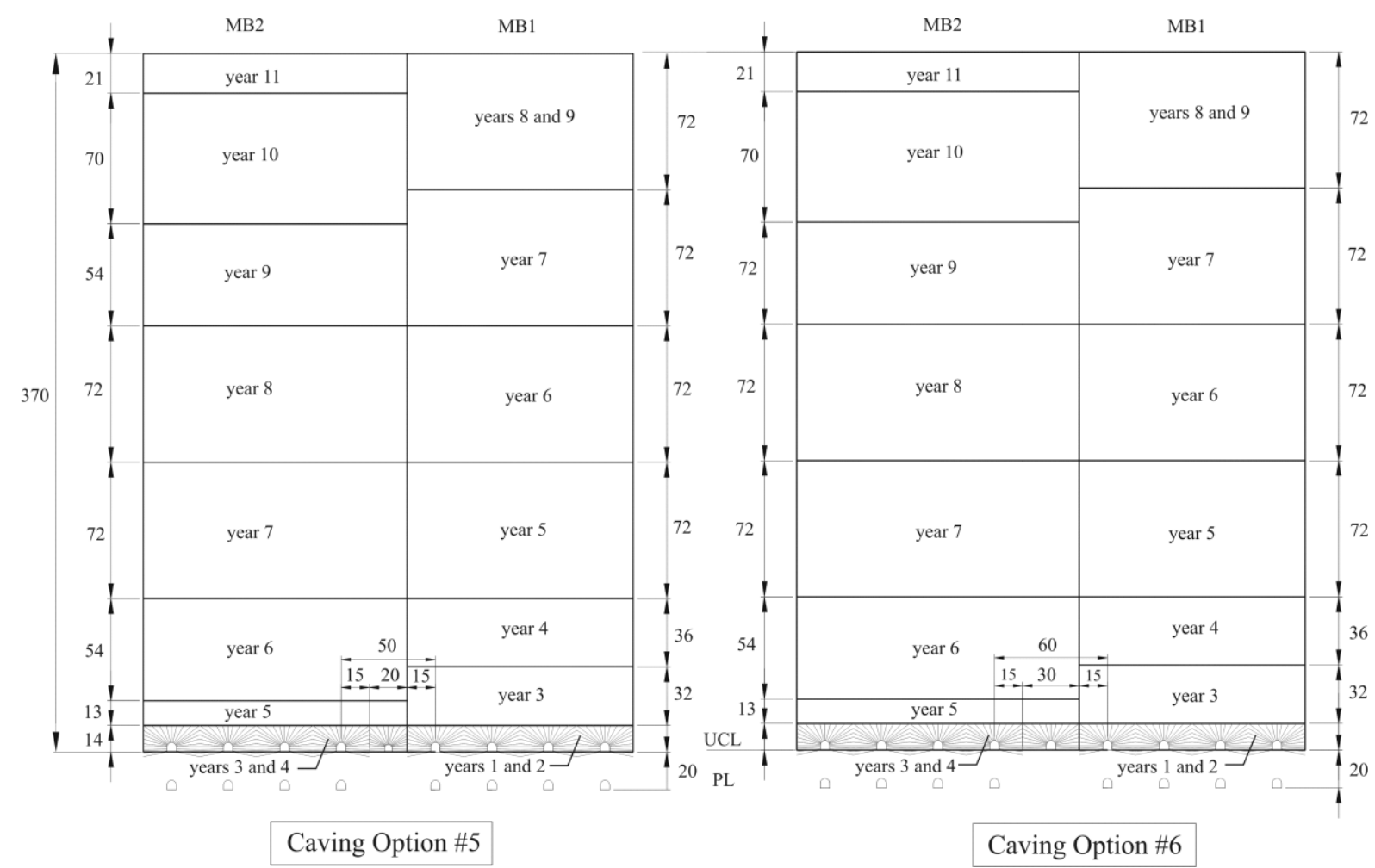

Figure 5 Caving options \#5 to \#6 analysed by 3D elasto-plastic models

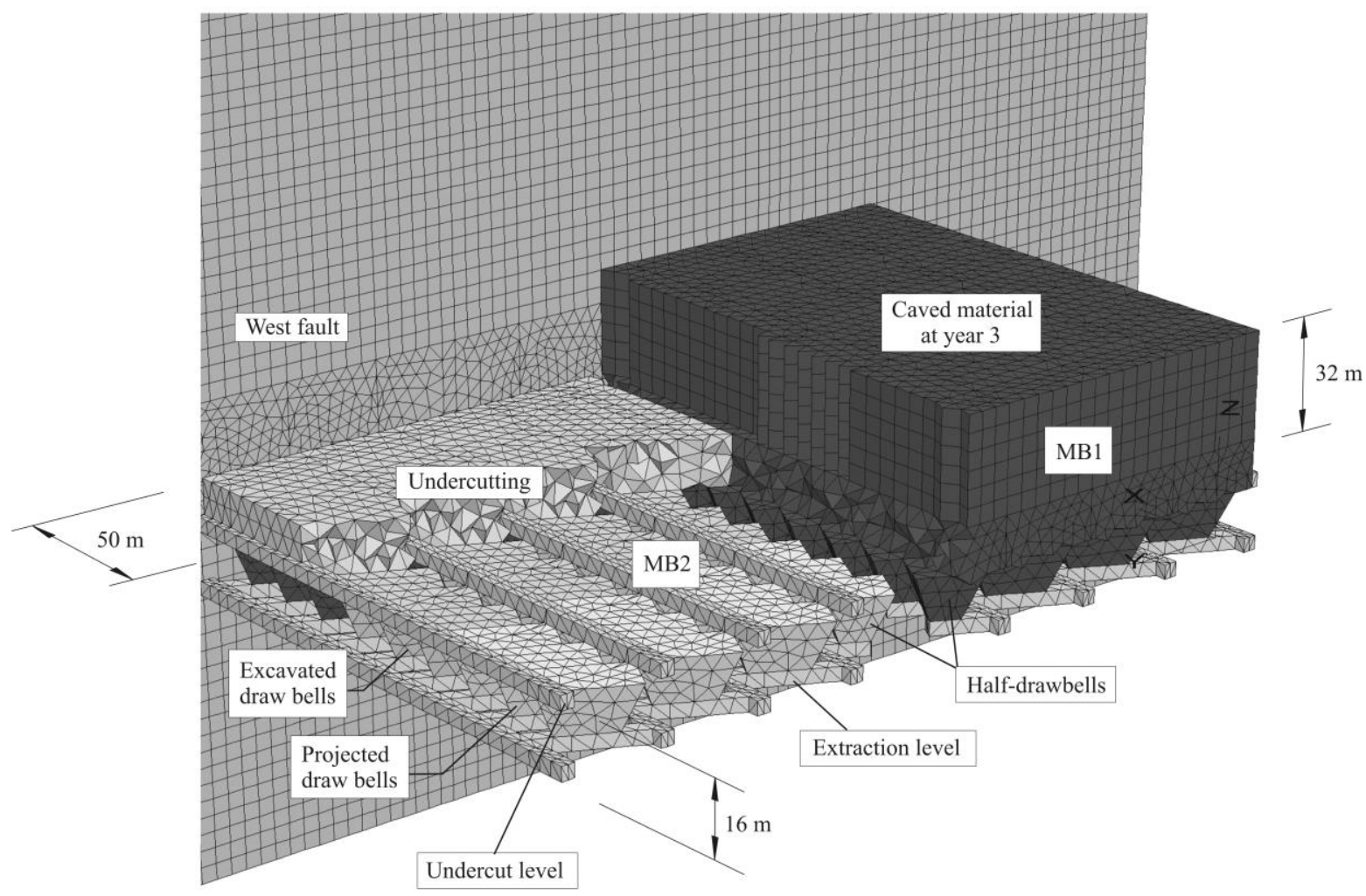

Figure 6 View of the 3D numerical model for caving option \#5 (year 3). This stage considers the extraction of approximately $32 \mathrm{~m}$ of ore column for macro-block unit MB1 (on the right side of the figure); and a $50 \times 95 \mathrm{~m}$ undercut area with nine excavated drawbells for unit MB2 


\section{$4 \quad$ Numerical models results}

The following is a summary of results obtained from the numerical study carried out for Chuquicamata underground project, as reported in detail in SRK Consulting Ltda. (2008):

1. In general, the abutment stress reaches $75-85 \mathrm{MPa}$ for caving option \#1 and \#2, whilst the abutment stress for others options is lower than $50 \mathrm{MPa}$ - see Figure 7.

2. High abutment stresses are concentrated within the RQS $(\mathrm{Q}>\mathrm{S})$ geotechnical unit whilst high cumulative deformations occurs for RQS $(\mathrm{Q}<\mathrm{S})$ and $\mathrm{RQS}(\mathrm{Q}=\mathrm{S})$ geotechnical units, both for options \#1 and \#2, as shown in Figure 8.

3. Extensive low stress zones represented by the minor principal stress are observed $10 \mathrm{~m}$ below the extraction level for options \#3 to \#6. The low stress zone for options \#1 and \#2 is significantly smaller compared to the other options, as shown in Figure 9.

4. Figure 10 shows the stress path for a point located $10 \mathrm{~m}$ above the extraction level floor in the macro-block pillar. For caving options \#1 and \#2, the peak strength of the rock mass is exceeded at year 3 (undercutting of MB2), while for options \#3 and \#4, the peak strength of the rock mass is exceeded at year 2 (undercutting of MB1). For options \#5 and \#6, significant stress reduction that would induce potential de-confinement (de-stressing) failure mechanisms is observed at year 3 .

5. Figure 11 shows the stress path for a point located $2 \mathrm{~m}$ above the extraction level floor in the macro-block pillar. For options \#1, \#2, \#3 and \#4, the peak strength of the rock mass is not exceeded at any year (no failure occurs). For options \#5 and \#6, significant stress reduction that would induce potential de-confinement (de-stressing) failure mechanisms is observed at year 3 . 

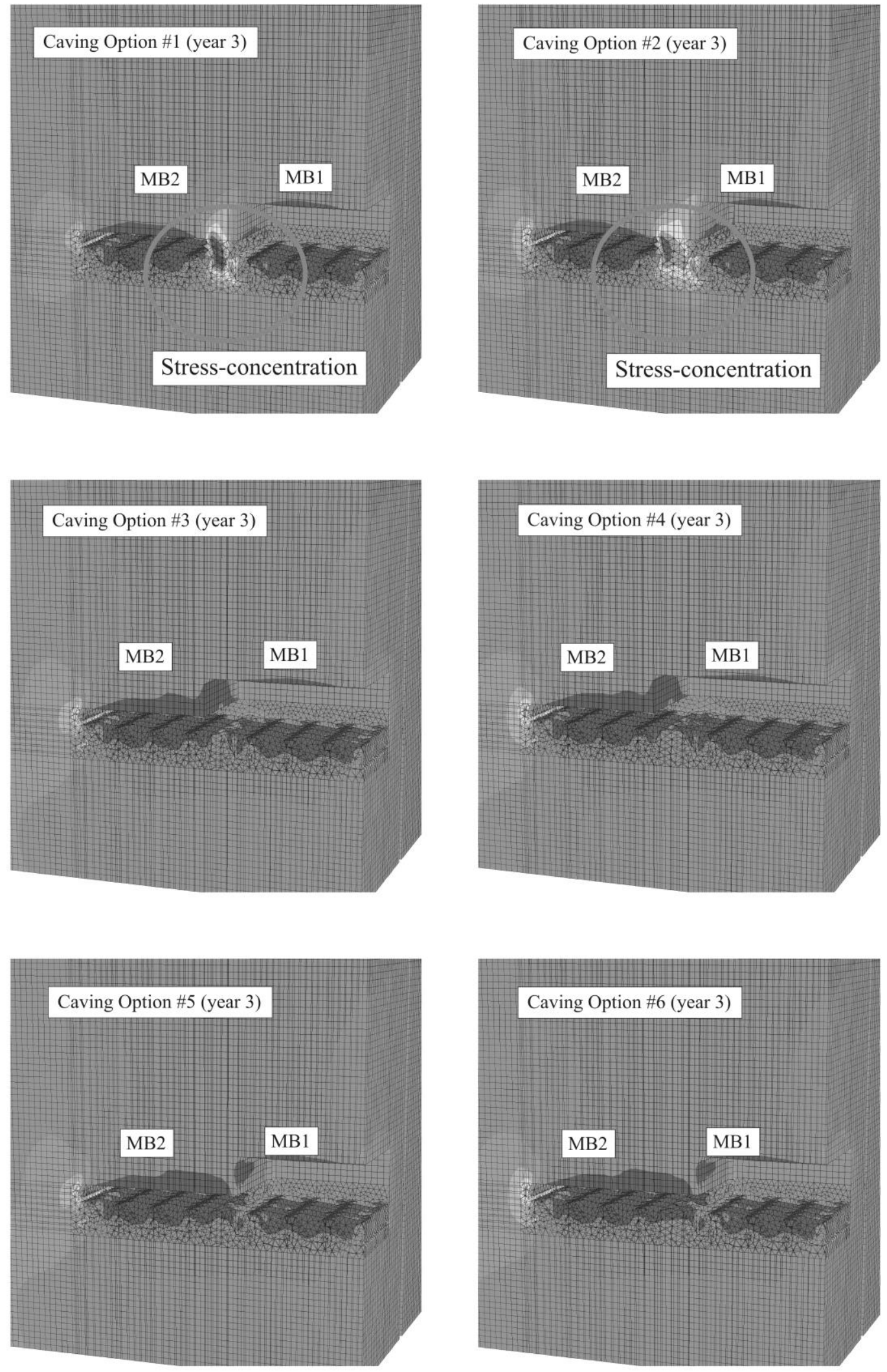

Contours of Major Principal Stress [in $\mathrm{MPa}$ ]
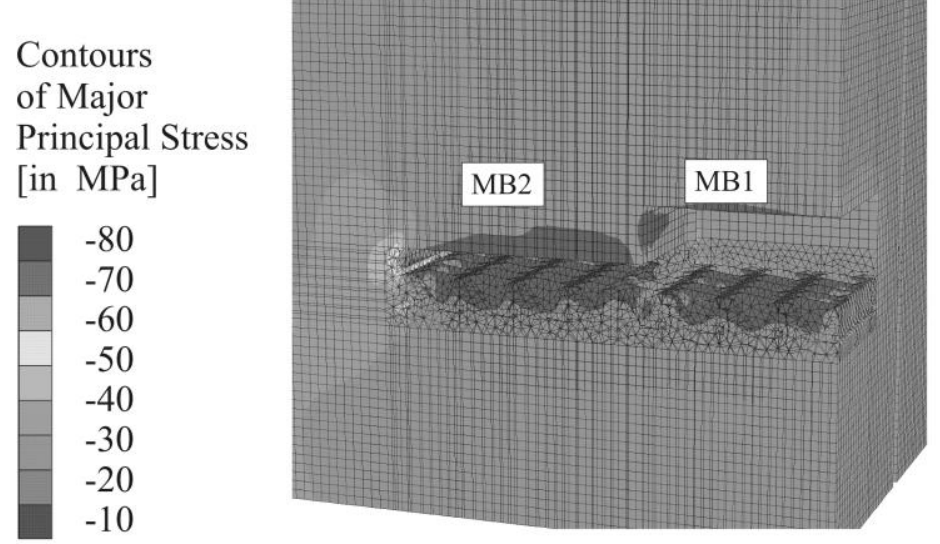

Figure 7 Comparison of different caving options in terms of major principal stresses. Note the abutment stress concentration in macro-block pillar for caving options \#1 and \#2 
a)

Model

Geotechnical

Units

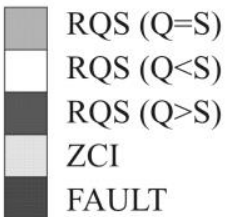

b)

Contours of Major Principal Stress [MPa]

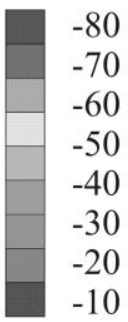

c)

Cumulative shear strain contouring [no units]

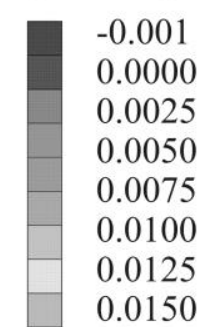

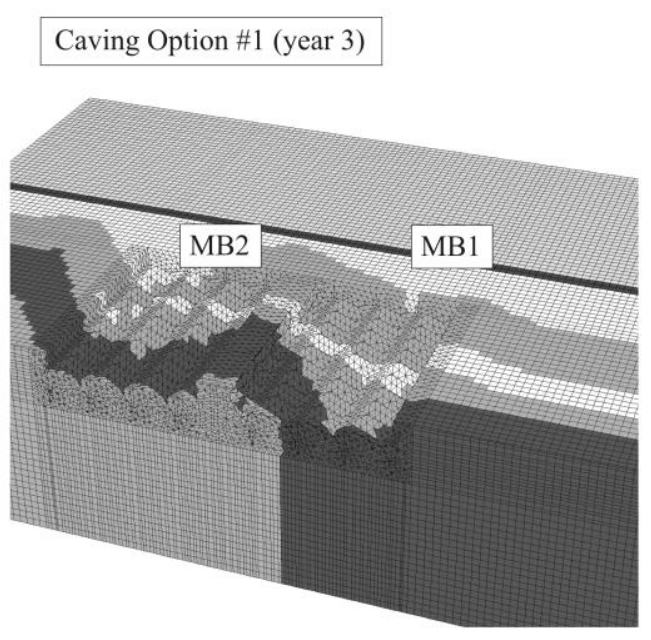
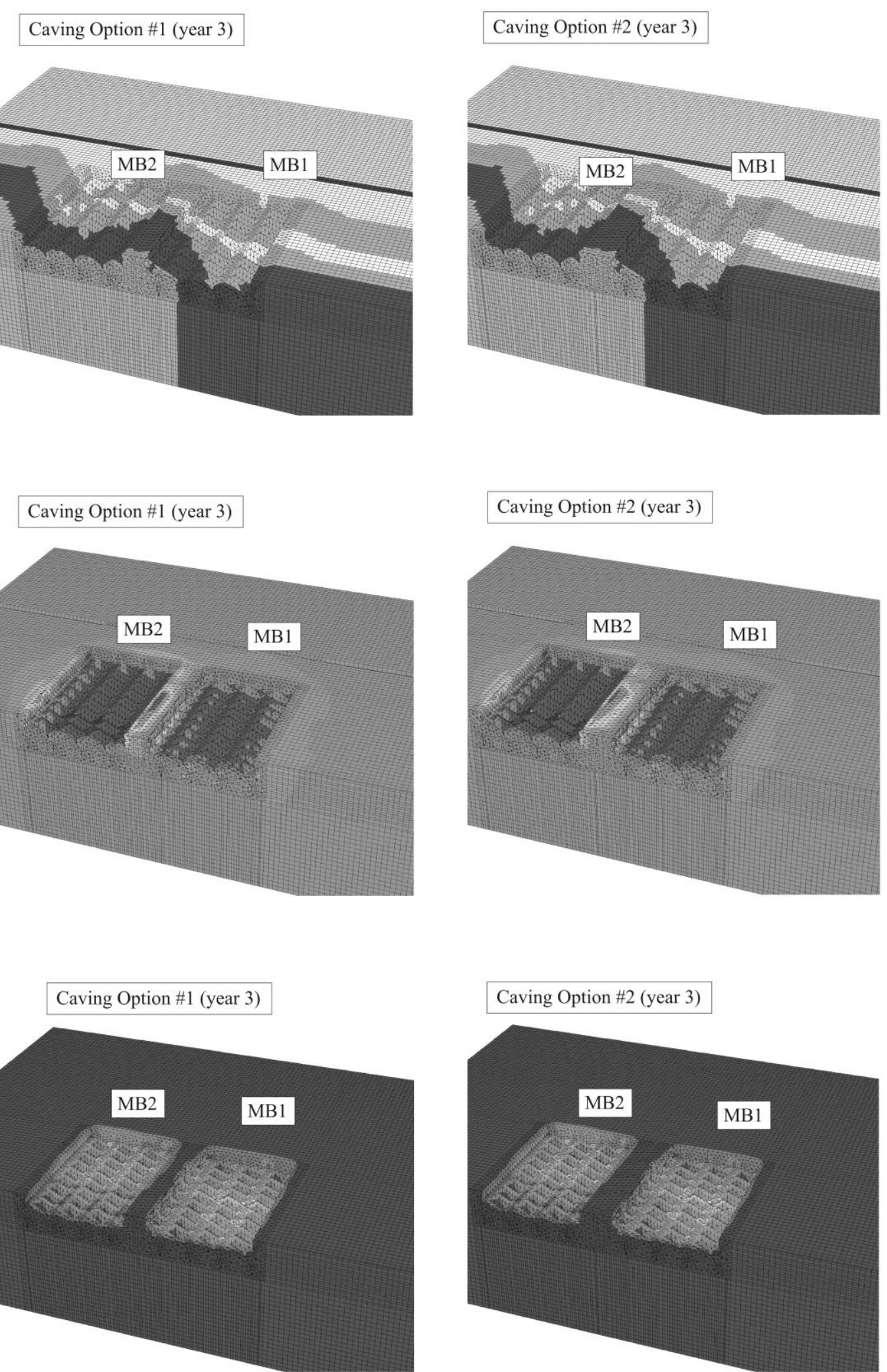

Figure 8 Representation of results in the model sliced by a horizontal plane located at the roof of the undercut level for caving options \#1 and \#2. a) Geotechnical units; b) abutment stresses for geotechnical unit RQS (Q>S) of good quality; c) shear strain increment for geotechnical unit $R Q S(Q<S)$ of poor quality 

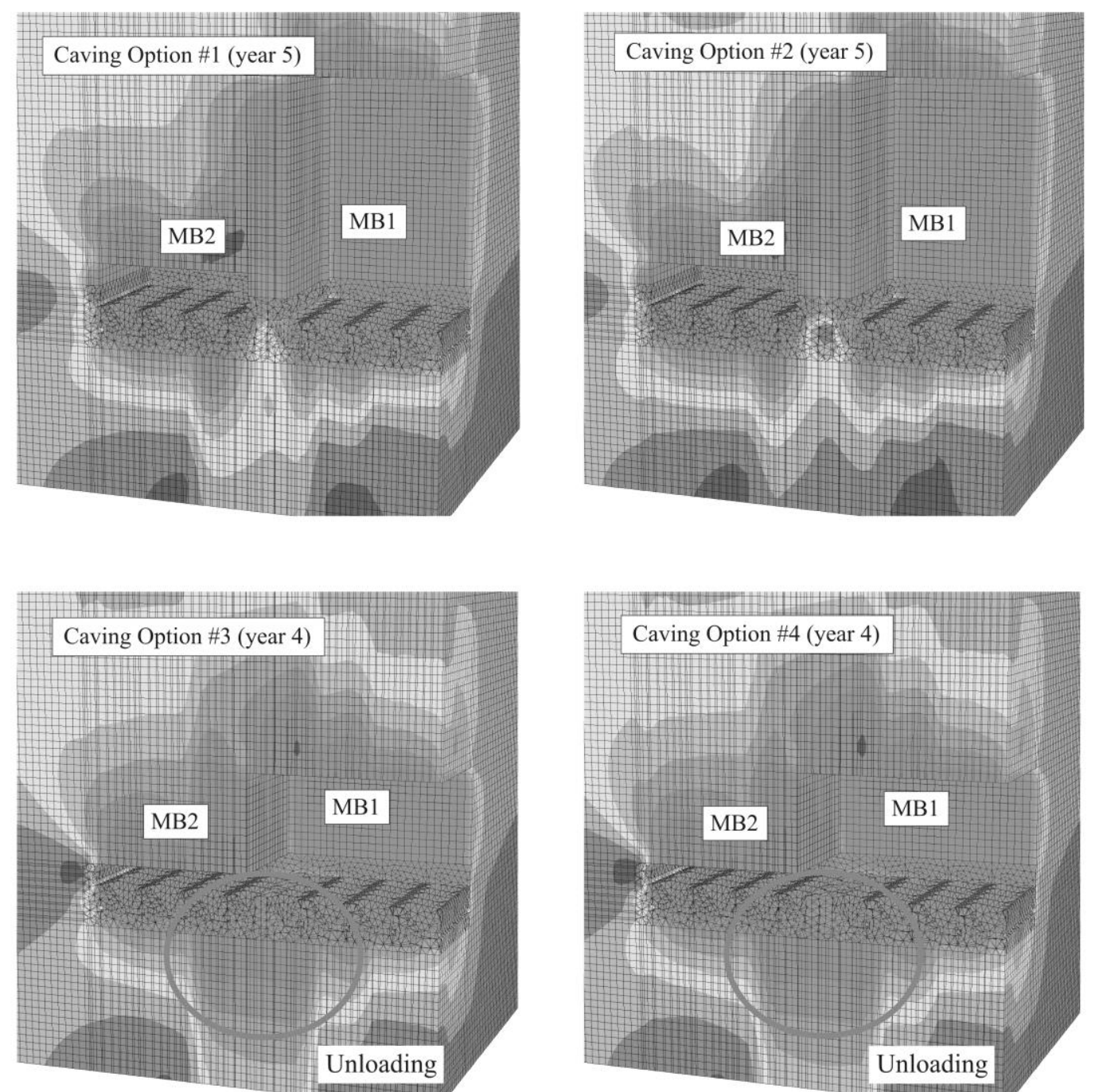

Contours

of Minor

Principal Stress

[MPa]

$-25.0$

$-22.5$

$-20.0$

$-17.5$

$-15.0$

$-12.5$

$-10.0$

$-7.5$
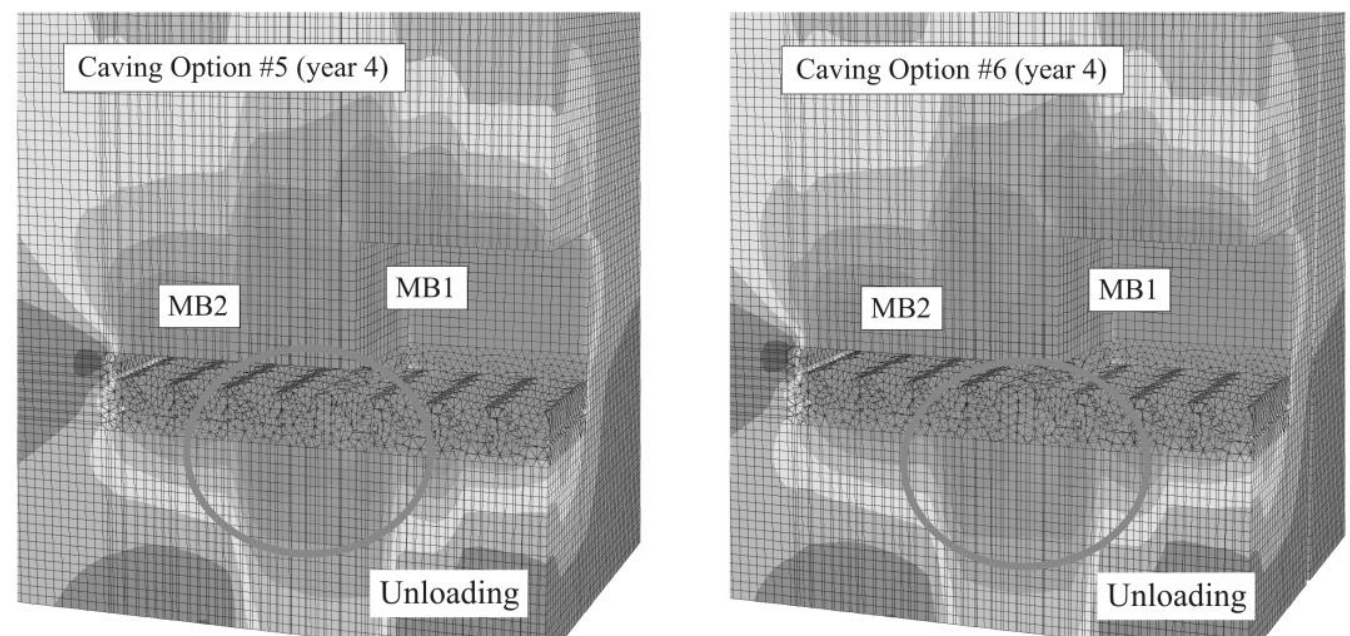

Figure 9 Comparison of different caving options in terms of minor principal stresses. Note the extension of low stress zones below the extraction level for caving options \#3, \#4, \#5 and \#6 


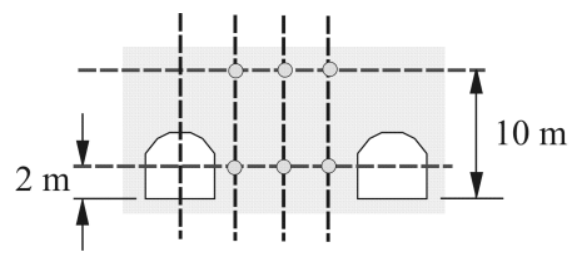

\begin{tabular}{c|c|l} 
PHASE & YEAR & \multicolumn{1}{|c}{ DESCRIPTION } \\
\hline 01 & 01 & Construction of Undercutting drifts for MB1. \\
05 & 02 & Drawbells opening for MB1 and first undercutting for MB1. \\
07 & 02 & Third undercutting for MB1. \\
09 & 03 & Extraction of 32m column of MB1. Layout MB2 construction. \\
13 & 03 & Third undercutting of MB2. \\
17 & 07 & Extraction of $284 \mathrm{~m}$ column of MB1 and 126 m column of MB2. \\
21 & 11 & Extraction of $100 \%$ of MB1 and MB2.
\end{tabular}

Caving Option \#1

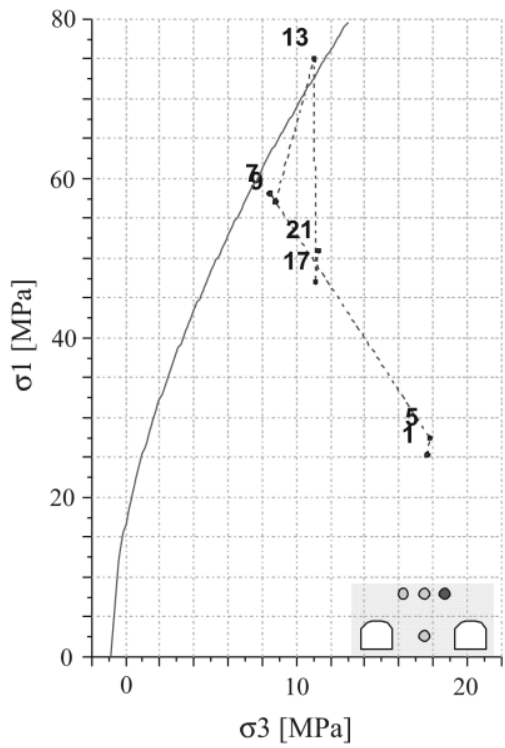

Caving Option \#4

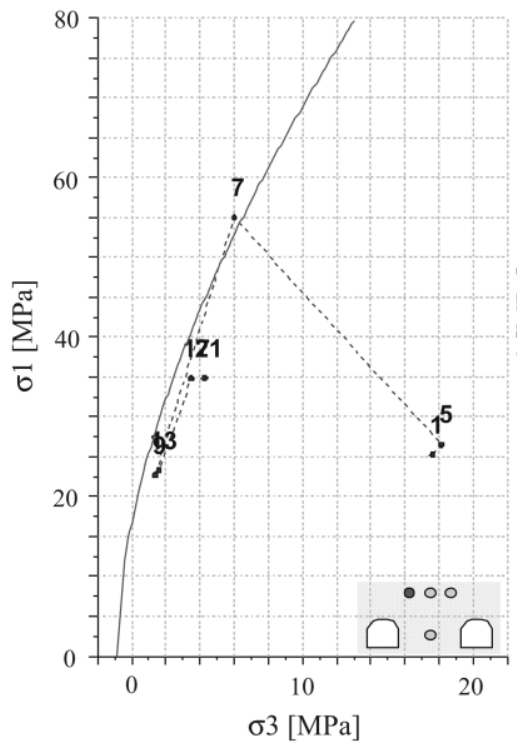

Caving Option \#2

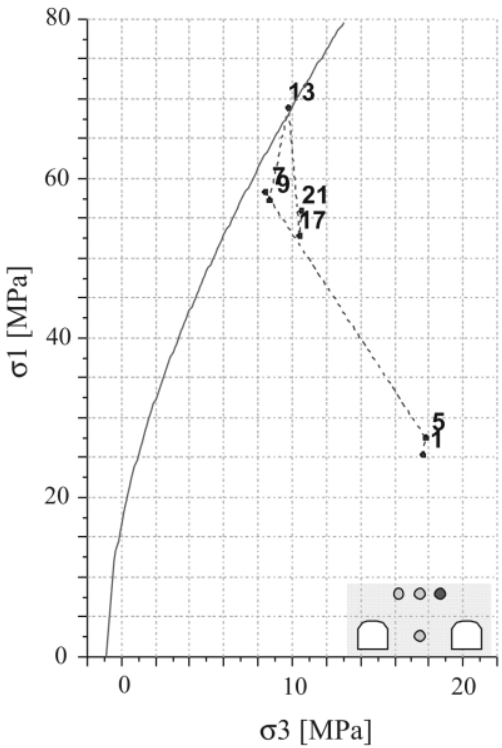

Caving Option \#5

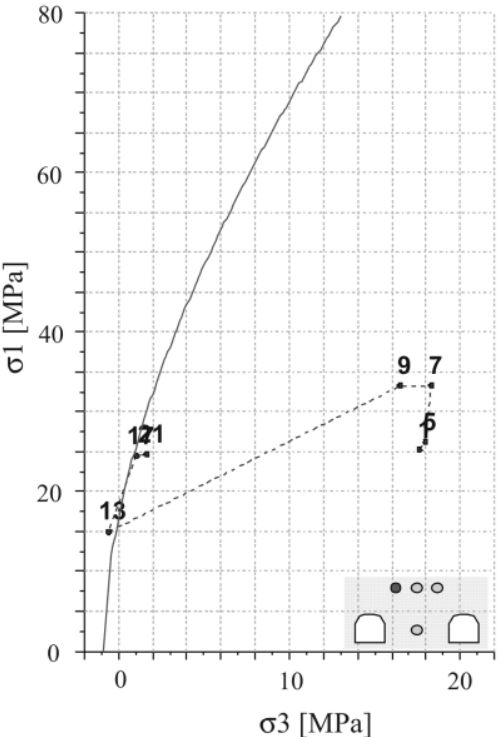

Caving Option \#3

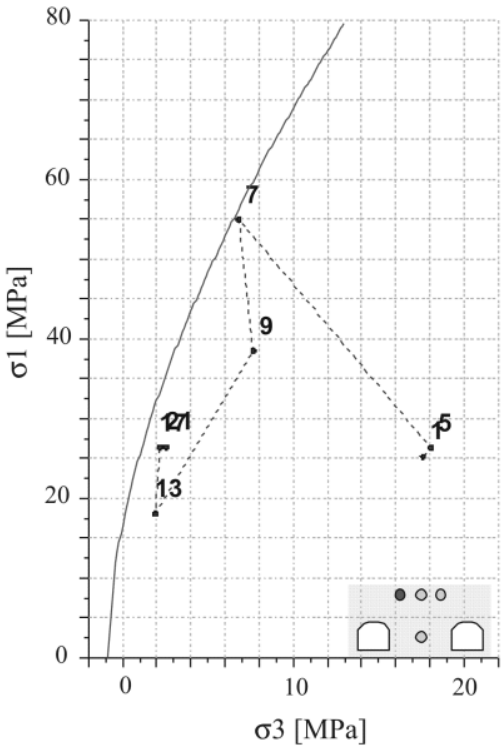

Caving Option \#6

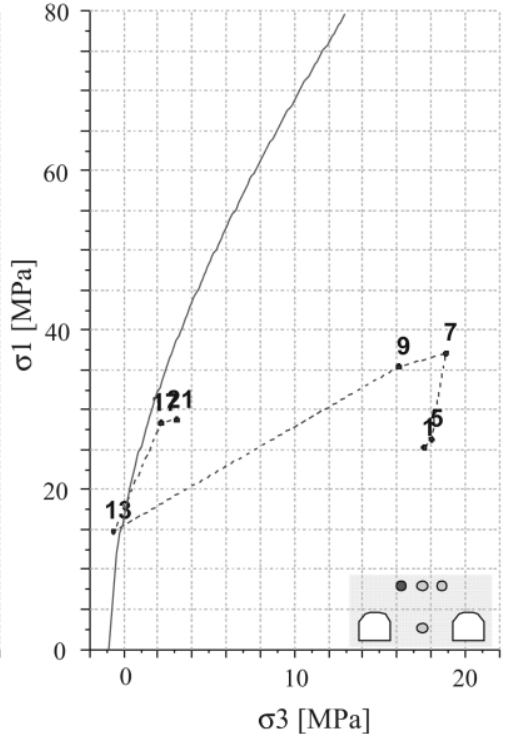

Figure 10 Stress paths and Hoek-Brown failure envelope for control points located inside the macroblock, $10 \mathrm{~m}$ above the extraction level floor. For caving options \#1 and \#2, the peak strength of the rock mass is exceeded at year 3 (undercutting of MB2); for caving options \#3 and \#4, the peak strength of the rock mass is exceeded at year 2 (undercutting of MB1); for caving option \#5 and \#6, potential failure induced by significant stress reduction (relaxation or de-stressing) can be observed at year 3 (induced by undercutting MB2) 


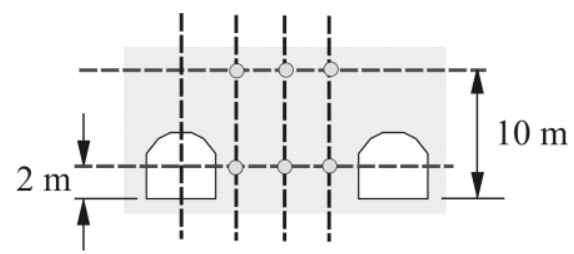

\begin{tabular}{c|c|l} 
PHASE & YEAR & \multicolumn{1}{|c}{ DESCRIPTION } \\
\hline 01 & 01 & Construction of Undercutting drifts for MB1. \\
05 & 02 & Drawbells opening for MB1 and first undercutting for MB1. \\
07 & 02 & Third undercutting for MB1. \\
09 & 03 & Extraction of 32m column of MB1. Layout MB2 construction \\
13 & 03 & Third undercutting of MB2. \\
17 & 07 & Extraction of 284m column of MB1 and 126 m column of MB2. \\
21 & 11 & Extraction of 100\% of MB1 and MB2.
\end{tabular}

Caving Option \#1

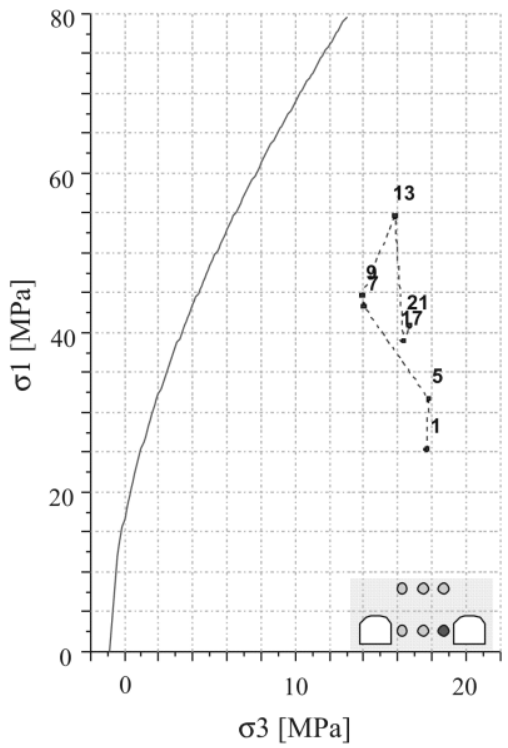

Caving Option \#4

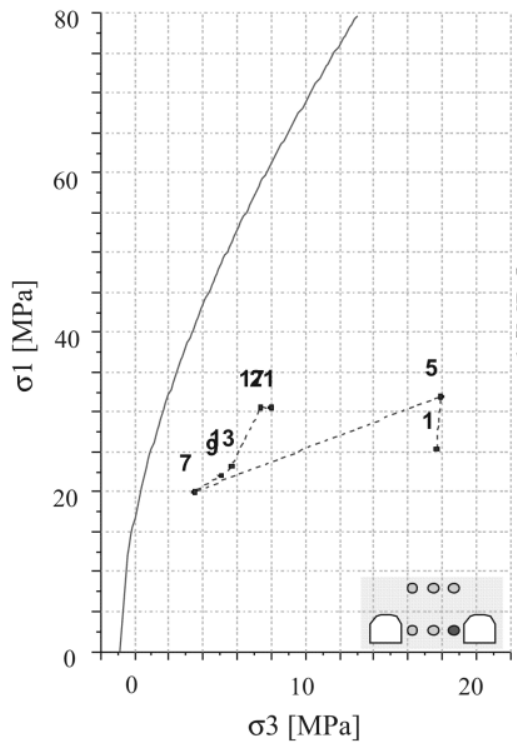

Caving Option \#2

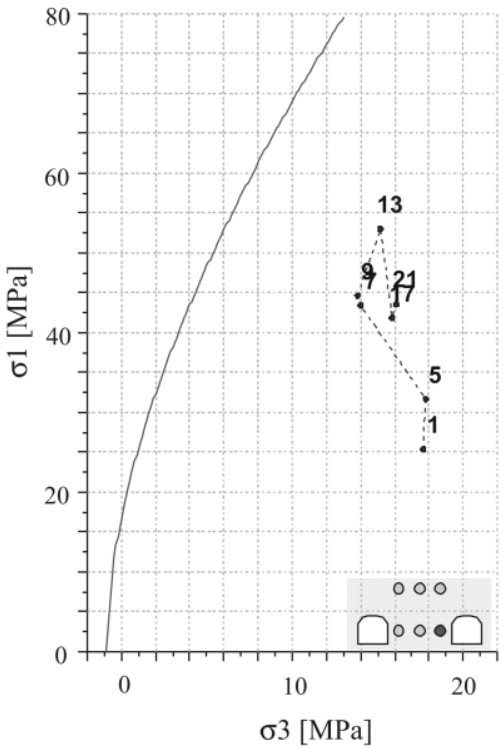

Caving Option \#5

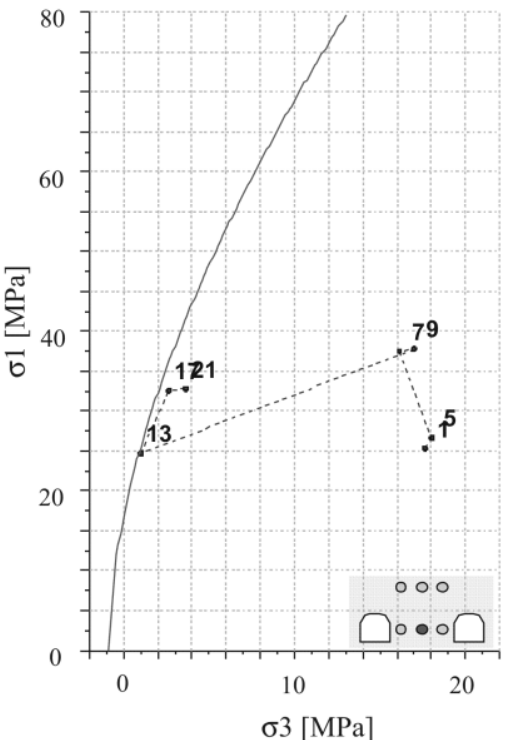

Caving Option \#3

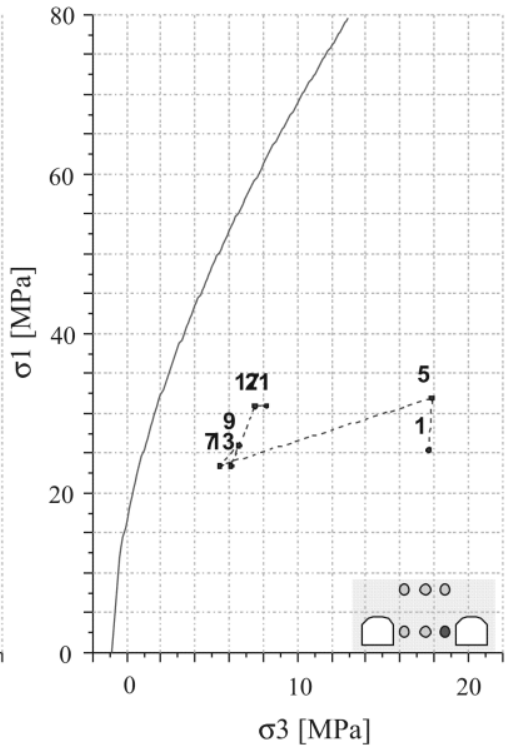

Caving Option \#6

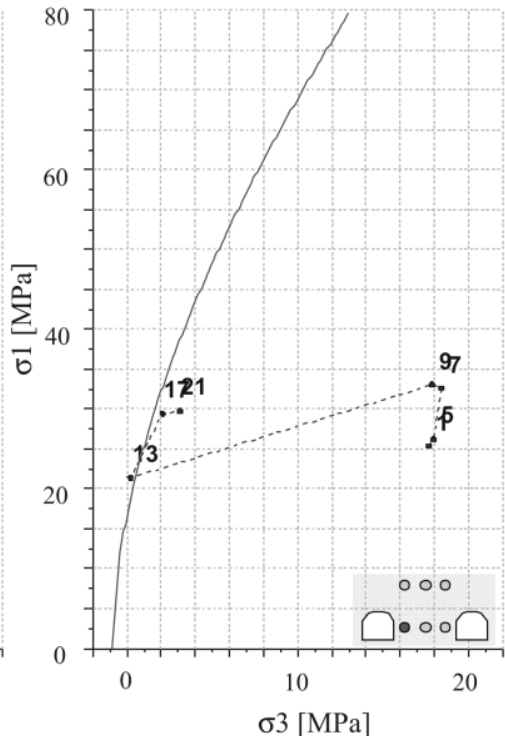

Figure 11 Stress paths and Hoek-Brown failure envelope (curved line) for control points located inside the macro-block, $2 \mathrm{~m}$ above the extraction level floor. For caving options \#1, \#2, \#3 and \#4, the peak strength of the rock mass is not exceeded in any year (no failure occurs); for caving options \#5 and \#6, potential failure induced by significant stress reduction (relaxation or de-stressing) can be observed at year 3 (induced by undercutting MB2) 


\section{Conclusion}

This paper has presented a general description of a geomechanical stress analysis performed for the Chuquicamata underground project in Chile. Based on geological and geotechnical characterisation of the site, and by using 3D elasto-plastic numerical models, stability for the macro-block caving options proposed for the project, has been assessed.

The results obtained from the analyses suggest that caving option \#6 leads to a smaller abutment stress concentration. Additionally for option \#6, the analysis suggests significant stress reductions (or de-confinement), that could potentially trigger several geotechnical instabilities. It should be mentioned, nevertheless, that in this engineering design stage, no support has been considered for the underground caving infrastructure; thus stability of galleries and drifts could be improved by support installation.

The numerical models developed for this project do not simulate the actual propagation of caving - rather they account for a front of 'broken' material that advances in time, as dictated by the given sequencing of excavation. In the next feasibility stage, it is recommended that caving propagation is better taken into account, e.g. by simulating evolution of the front using softening/strength reduction schemes.

\section{Acknowledgements}

The authors would like to thank Codelco (National Copper Corporation of Chile), and in particular, Sergio Fuentes, project manager and Sergio Olavarria, project director of Chuquicamata underground project, for granting permission to publish this paper.

\section{References}

Codelco (2007) Geología y Recursos Minerales para la Ingeniería Conceptual del Proyecto Chuquicamata Subterráneo, Subgerencia de Geología, Dirección de Geología de Desarrollo, División Codelco Norte, Codelco, Chile.

VCP-Codelco (2009) Estudio de Prefactibilidad Proyecto Chuquicamata Subterráneo API N07DM43, VCP, Codelco, Chile.

Hoek, E. (1994) Strength of rock and rock masses, ISRM News Journal, Vol. 2(2), pp. 4-16.

Hoek, E., Carranza-Torres, C. and Corkum, B. (2002) Hoek-Brown Failure Criterion, 2002 Edition, in Proceedings 5th North American Rock Mechanics Symposium and 17th Tunneling Association of Canada Conference, R. Hammah, W. Bawden, J. Curran and M. Telesnicki (eds), University of Toronto Press, Toronto, Vol. 1, pp. 267-273.

HCItasca-SRK (2006) Complementary Geotechnical Studies for Conceptual Design of an Underground Mine at Chuquicamata, HCItasca-SRK, Vancouver, Canada.

Karzulovic, A. (2007) Revisión Caracterización Geológico Geotécnico Proyecto Mina Chuquicamata Subterránea, PMCHS MSC-ICO-AKL-2000-GEM-INF-001-REV P, A. Karzulovic and Asoc. Ltda., Chile.

Laubscher, D.H. (1990) A Geomechanics Classification System for the Rating of Rock Mass in Mine Design, Journal of South African Institute of Mining and Metallurgy, Vol. 90(10).

SRK Consulting Ltda. (2009) Trabajos Geomecánicos Complementarios Proyecto Chuquicamata Subterráneo, Technical report MSC-ICO-SRK-2000-GTE-INF-002-Rev P, SRK Consulting Ltda. Santiago, Chile.

SRK Consulting Ltda. (2008) Evaluación Geomecánica de la Malla de Extracción Proyecto Mina Chuquicamata Subterránea, Technical report MSC-ICO-SRK- 2000-GTE-INF-001-Rev P, Santiago, Chile. 